\title{
and Health (ICASSETH 2019) \\ Analysis of the Difficulty of Students on Visualization Ability Mathematics Based on Learning Obstacles
}

\author{
Ferry Ferdianto*, Sinta Hartinah \\ Pendidikan Matematika \\ Universitas Swadaya Gunung Jati \\ Cirebon, Indonesia \\ *ferry.ugj@gmail.com, sintahartinah25@gmail.com
}

\begin{abstract}
This research based on the students who have a difficulty solving Sistem Persamaan Linear Tiga Variabel (SPLTV) problems. The difficulty can be seen from the mistakes made by students when solving SPLTV problems. Student mistakes result in learning obstacles when understanding and solving SPLTV problems. One factor causing this to happen is the lack of students' mathematical visualization abilities. This research aimed to determine the students' mathematical visualization abilities based on ontogenic obstacles. The method used in this research is a qualitative descriptive method by identifying answer mistakes made by students when conducting a written test in the form of a description of the questions then the results of the answers are analysed according to learning obstacles that occur in students. The analysis was also strengthened by the answers of the students' interviews. The results showed that there were jumps in thinking experienced by students in the form of jumps from arithmetic thought patterns to algebraic mind-set. Which is a learning obstacle that is ontogenic obstacles. So in general students' mathematical visualization abilities based on ontogenic obstacles experienced by students are relatively low.
\end{abstract}

Keywords: visualization ability, ontogenic obstacles, student difficulties, SPLTV

\section{INTRODUCTION}

Algebra is one of the scopes of mathematics that studies simplification and problem solving using symbols, then the symbols are used to present numbers in general as a means of simplification and aids in solving problems. This is in line with the opinion Putri, and Manoy [1] that algebra is a branch of mathematics that studies simplification and problem solving using certain symbols. Algebra is studied at various levels of education in Indonesia. Algebra is also divided into several subjects at each level, one of which is the Three Variable Linear Equation System (SPLTV).

In the education curriculum 2013 revised edition of 2017 , the SPLTV material is given to high school students in grade X mathematics for both Natural Sciences and Social Sciences. Indicators of SPLTV competency achievement in the 2013 curriculum include: 1) composing a mathematical model of contextual problems into the form of a three-variable linear equation system, 2) determining the set of solutions of a threevariable linear equation system by the method of substitution, elimination, combined method (substitution-elimination), and determinant methods, and 3) solve contextual problems related to the three-variable linear equation system. But in the implementation of these learning indicators cannot be met properly. The grades obtained by students in the SPLTV chapter are also relatively low when compared to other chapters contained in the compulsory grade $\mathrm{X}$ mathematics material.

This is consistent with the initial research that has been conducted Hartinah, and Ferdianto [2] found that many students had difficulty in making mathematical models and solving SPLTV problems. Student difficulties have been seen when students make mathematical models, there are still many students who make mistakes when modelling. Not only that mistakes also continue when students solve SPLTV problems, but students also make mistakes in the counting operation process. The results of a preliminary study of the errors and difficulties that are often made by students in answering SPLTV questions to several high school students found that the mistakes students often made were in understanding the purpose of the questions and making mathematical models. Many of the students make mistakes when processing completion. Some of these student mistakes can be seen in the picture as follows.

The questions are given, a swimming pool set the entrance ticket price of Rp. 7,000.00 for visitors under the age of 7 years old, Rp. 10,000 for students and Rp. 15,000 for the public. One day the swimming pool can sell 143 tickets with a total reception of $\mathrm{Rp} 1,541,000.00$. If the number of student tickets sold is 16 fewer than twice the number of tickets for children aged less than 7 years. How many tickets were sold for each ticket? 


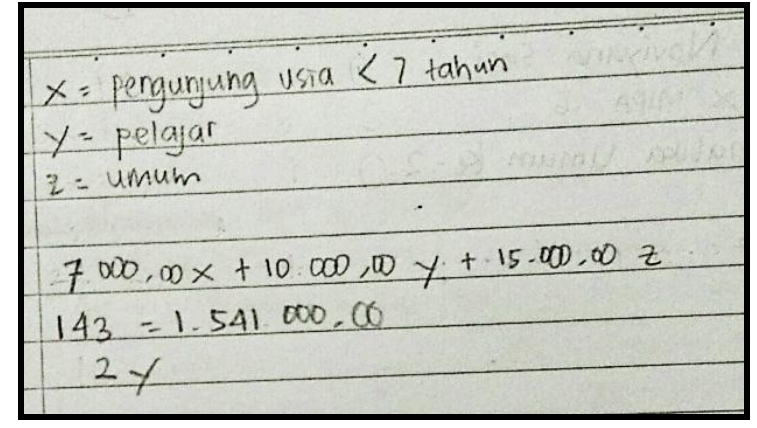

Fig. 1. Student answers.

In Figure 1, it can be seen that students can make an example even though it is not yet fully correct. Students assume $\mathrm{x}$ as a visitor less than 7 years old, $\mathrm{y}$ as a student and $\mathrm{z}$ as a general. This is because the correct example should be $\mathrm{x}$ as the number of tickets aged less than 7 years old, $y$ as the number of tickets for students sold and $\mathrm{z}$ as the number of tickets for the public that were sold. The mathematical model made by students is also not right, where the model made by students is the first $7,000 \mathrm{x}+10,000 \mathrm{y}+15,000 \mathrm{z}$, then the second $143=1,541,000$ and the third $2 y$. The right model is $7,000 \mathrm{x}+10,000 \mathrm{y}+15,000 \mathrm{z}=1,541,000 ; \mathrm{x}+\mathrm{y}+\mathrm{z}=143$ and $\mathrm{y}=2 \mathrm{x}-16$. Seen students still have difficulty in making mathematical models of these problems.

Many factors cause students to experience difficulties in solving mathematical problems in SPLTV material, one of which is the lack of students' visualization abilities. This can be seen in Figure 1 where students have not been able to visualize and model story problems, students also have not been able to connect between known data with the concepts they have and also students have not been able to determine problem solving with various methods of solving.

Visualization ability is the most basic and important ability in learning SPLTV material. Elvi [3] argues that visualization can help students in exploring mathematical problems and provide an understanding of mathematical concepts and the relationships between these concepts. Whereas Dewi [4] argues that in mathematics learning visualization is a powerful tool for investigating mathematical problems and also for giving meaning to a mathematical concept and the relationship between concepts and problems. Librianti and Sugiarti [5] asserted that in solving mathematical problems needed a good ability of imagination and the ability to represent well to find solutions to problems. Whereas Haas [6] stated four characteristics of visual ability 1) imagination, 2) conceptualization, 3) problem solving, and 4) pattern search.

Based on Septyawan [7] the lack of students in visualization skills certainly has the potential to cause learning obstacles in learning SPLTV and has implications for the lack of optimal student knowledge related to the concept. It also added that to explore the possibility of learning obstacles must consider the overall point of view and its relevance. While Saifiyah et al. [8] argues that the existence of learning obstacles makes students lazy to learn mathematics and also work on existing problems. This is reinforced by the research that has been done Rohimah [9] on the subject of algebraic material in equations and linear inequalities of one variable. He found that the material contained learning obstacles in students, learning obstacles included ontogenic obstacle, epistemology obstacle and didactical obstacle. This is in line with the categories put forward Brousseau [10] of learning obstacles that occur in students, namely epistemological obstacle (obstacles due to limited understanding of students), ontogenic obstacle (obstacles due to the readiness and maturity of student congregations) and didactical obstacles (obstacles due to the stages and sequence of presentation of material ). But in this study the author only discusses ontogenic obstacles. The purpose of this study was to determine the students' mathematical visualization abilities based on ontogenic obstacles.

\section{RESEARCH Methodology}

The research method used in this research is descriptive qualitative research. The study was conducted at SMAN in Cirebon with research subjects for all students of class X MIPA 6 in 2018/2019. Data collection techniques used were written tests and interviews. The data analysis technique used is to analyse the mistakes made by students using the Newman category error analysis and proceed with the analysis of learning obstacles that are ontogenic obstacles.

\section{RESULTS AND DISCUSSION}

In this study the questions were tested on students of class X MIPA 6 SMAN 4 Cirebon in the 2018/2019 school year. Once identified, there are five categories of errors that students often make when solving SPLTV problems according to the Newman category, namely reading errors, misunderstandings, transformation errors, process skills errors, and mistakes in writing the final answer.

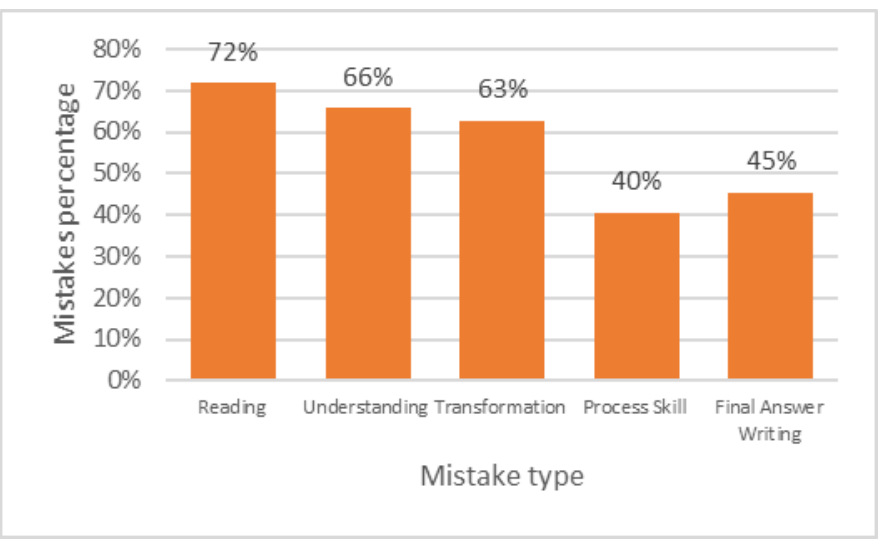

Fig. 2. Percentage of student mistakes.

Based on Figure 2, it can be seen that the most mistakes made by students start from the first stage, namely at the reading stage. Furthermore, the second most common error experienced by students is at the understanding stage. Furthermore, the third most mistake is at the stage of transforming, which in this case transforms from the SPLTV problem presented in the form of a story problem into an equation or mathematical model. 


\section{A. Forms of Error in the Reading Stage}

At the reading stage as much as $71.72 \%$ of students could not go through the stage of reading or recognizing symbols, terms or words contained in the problem properly. Even though students can read the questions fluently, the writer finds that students cannot interpret the sentences they read correctly and cannot read the keywords or symbols written on the questions correctly.

\section{B. Forms of Error in the Understanding Stage}

At the reading stage as much as $65.66 \%$ of the authors pay attention to students not being able to understand the problem well where students cannot write what is known and asked in the problem. This is proven by none of the students who think about variables correctly. In question number two students consider motorbikes, minibuses and buses as variables, not the number of motorbike vehicles, minibuses and parked buses.

Likewise, in question number three none of the students assumed the variables correctly, in question number three students assumed Yanti, Nia and Susi as variables, instead of the time needed for Yanti, Nia and Susi to complete the mat. Whereas in question number one the sentence that is considered difficult is if the longest side length of the flag is ten centimetres shorter than three times the length of the shortest side and the number of other sides. Only a few students understand the sentence well.

\section{Forms of Error in the Transformation Stage}

As many as $62.63 \%$ made mistakes at the transformation stage. Errors occur when students transform the information they get in the problem into mathematical sentences or mathematical models correctly. The author suspects this is because students do not understand the meaning of the sentence. In problem number one, students do not understand correctly the keywords from the circumference of a triangle. Where the formula from the circumference of a triangle has obtained the sides of the triangle which will become variable.

In question number two, students feel confused about transforming the arithmetic operations contained in the problem into their mathematical models. If students understand that the area of the bus parking lot is three times the area of the motorcycle parking lot which means three times it means the multiple, then the student is easy to transform the problem. Whereas in question number three, none of the students can to transform into a mathematical model even though students can already know what is known and asked in the problem. This is because students forget the concept of fractions turned around grades. So the mathematical model made by students is not right.

\section{Forms of Error in the Process Skill Stage}

In the process skills stage as many as $40.40 \%$ of students make mistakes in performing mathematical procedures, where errors occur in the process of elimination, substitution, elimination-substitution, and determinants when performing multiplication, addition and subtraction operations

\section{E. Forms of Error in the Final Answer Writing Stage}

As many as $45.45 \%$ of students make mistakes at the stage of writing the final answer. Many students write a short answer and do not represent the information asked in the problem.

Some students have been able to visualize and solve SPLTV problems. But many students have not been able to visualize well or even cannot visualize the problem of SPLTV at all. So that this certainly affects the process of completion by students of these problems. Students also have not been able to connect the known data with the concepts they have. In addition, students also tend not to be able to find patterns in solving SPLTV problems.

The lack of students 'mathematical visualization abilities and the mistakes students often make when completing SPLTV problems have been described, but this does not necessarily guarantee that students' problems are limited to making these mistakes. Therefore, it is important to explore the possibility of learning obstacles experienced by students in the SPLTV concept. Based on the analysis of errors that have been made, it is found that there are learning obstacles in the SPLTV material, namely ontogenic obstacles.

In this research, Ontogenic Obstacles were found because of the thinking jump experienced by students. Which leapfrogging is happening in the process of thinking artimatika to algebra. In addition, students also did not seem to understand well the meaning of the SPLTV concept. This was found when the authors conducted written tests and interviews with students. When the writer conducts interviews with students regarding concepts that students know about SPLTV students tend to answer that SPLTV is a variable besides that students are also directly focused on the method of completion used on SPLTV.

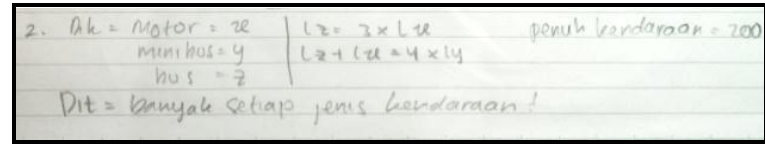

Fig. 3. Ontogenic obstacles findings.

In figure 3 it can be seen that students cannot think algebraically. Students only describe story problems in the form of artimatika not proceed to the algebra process. From the students 'answers, it was also seen that the students' mathematical visualization abilities of the given story problems were still lacking, because students could not visualize and model the problems. Students can only think about variables, although the variables made by students are also not entirely correct. Because there is a jump in thinking that occurs in students, so in the problem students make mistakes at the stage of understanding and transformation. When asked why the student answered question number 2 like that, the students themselves seemed unsure and answered that the modelling that students understood was like that.

In addition, students cannot think algebra can also be seen from the answer number 1 below: 


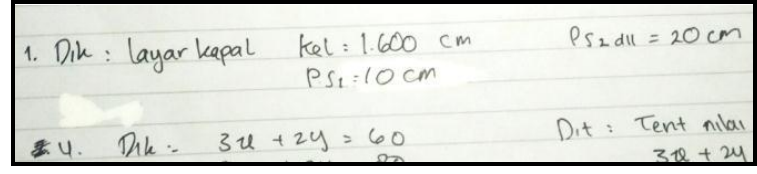

Fig. 4. Ontogenic obstacles findings.

In Figure 4 it was also found that there was a student's jump from the mind-set of artimatika to algebra. Students do not understand well the meaning of the problem. Students also have started to make mistakes at the reading stage which continues to the transformation stage. There was also a misunderstanding between the material taught by the teacher and received by students. When interviewed, students answered that what was meant by writing down what was known to the problem was a form of the mathematical model itself.

Still on question number 2, the writer found another answer that indicated that there were ontogenic learning obstacles that occurred in students as follows.

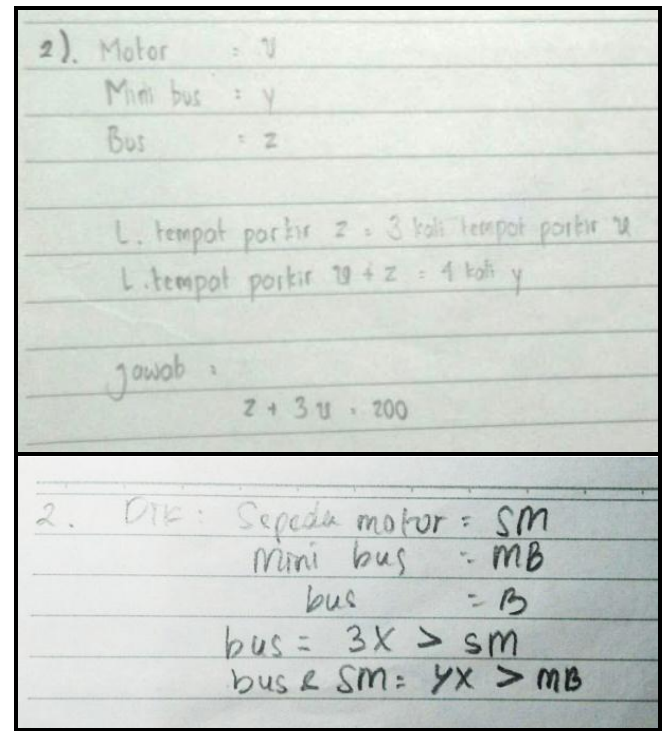

Fig. 5. Ontogenic obstacles findings.

In Figure 5, students are jumping from arithmetic to algebraic thinking. In Figure 5 part (a) students only write the information obtained in the problem in the form of arithmetic, but this is not passed on to algebraic information. This has an impact when the completion process, students cannot solve questions number 2 until completion. Because mathematical models that should be available to be operated or solved by suitable methods are not available. Likewise with the picture of part (b), students are still unable to continue the process of thinking from arithmetic to algebra.

The inconsistency of the SPLTV concept in students in solving SPLTV problems and the thinking jump experienced by students from the arithmetic mind-set to the algebraic mindset identifies that students are not fully ready to learn SPLTV any further. This can be seen from the number of students who do not fully know about the definition of the SPLTV concept following the essence of the SPLTV concept explained by mathematicians. In addition, it was also revealed that some students were not ready to deal with the key issues in the SPLTV questions such as what were the variables and how they were modelled. The answer "forget" from students when interviewed is an indication of students' unpreparedness in learning SPLTV material [11,12]. Some students also experience difficulties at the completion stage, so students have difficulty when faced with SPLTV questions, especially when presented in the form of story questions and with higher levels. This difficulty then impacts on students' motivation and enthusiasm in learning SPLTV material. Saifiyah [8] argues that the existence of motivation will make students more active in learning and have the courage to ask the teacher if there are difficulties in learning. This is what confirms that there are ontogenic obstacles in the SPLTV material [7]. So that students' mathematical visualization abilities on this SPLTV material tend to be lacking if viewed based on ontogenic obstacles experienced by students.

\section{CONCLUSIONS AND SUGGESTIONS}

Based on the analysis of the findings and discussion in this study, it can be concluded that there are learning obstacles on the SPLTV material, namely ontogenic obstacles. The inconsistency of the SPLTV concept in students in solving SPLTV problems and the thinking jump experienced by students from the arithmetic mind-set to the algebraic mind-set identifies that students are not fully ready to learn SPLTV any further. In addition, it was also revealed that some students were not ready to deal with the key issues in the SPLTV questions such as what were the variables and how they were modelled. Some students also experience difficulties at the completion stage, so students have difficulty when faced with SPLTV questions, especially when presented in the form of story questions and with higher levels. This difficulty then impacts on students' motivation and enthusiasm in learning SPLTV material. So that students' mathematical visualization abilities on this SPLTV material tend to be lacking if viewed based on ontogenic obstacles experienced by students.

\section{REFERENCES}

[1] L.F. Putri and J.T. Manoy, "Identifikasi Kemampuan Matematika Siswa dalam Memecahkan Masalah Aljabar di Kelas VIII Berdasarkan Taksonomi Solo,” Journal MATHEdunesia, vol. 2, no. 1, pp.1-8, 2013.

[2] S. Hartinah and F. Ferdianto, "Identifikasi Kesalahan Siswa Dalam Memahami Materi SPLTV," Prosiding Seminar Nasional Pendidikan Matematika (SNPM), vol. 1, no. 1, pp. 484-492, 2019.

[3] M. Elvi, Penerapan Model Pembelajaran Tutorial Berbantuan Geogebra untuk Meningkatkan Kemampuan Visual Thiking dan Self-Efficacy Siswa SMP (Penelitian Kuasi Eksperimen pada Salah Satu SMP di Kota Bandung) (Thesis), Bandung: Universitas Pendidikan Indonesia, 2016.

[4] M.R. Dewi, Pengaruh Model Quantum Teaching Terhadap Peningkatan Kemampuan Visual thiking dan Berpikir Kreatif Matematis Siswa SMP (Studi Kasus Eksperimen Siswa Kelas VIII pada Salah Satu SMP Negeri di Kecamatan Lembang) (Thesis), Bandung: Universitas Pendidikan Indonesia, 2016.

[5] V.D. Librianti and T. Sugiarti, "Kecerdasan Visual Spasial dan Logis Matematis dalam Menyelesaikan Maslah Geometri Siswa Kelas VIII A SMP Negeri 10 Jember (Visual Spatial and Logical Mathematical Intelligence in Solving Geometry Problems Class VIII SMP Negeri 10 Jember)," Artikel Ilmiah Mahasiswa, vol. I, no. 1, pp. 1-7, 2015.

[6] S.C. Haas, Algebra for Gifted Visual-Spatial Learners, 2003, [Online], Retrieved from: http://www.visualspatial.org/files/algebra.pdf. 
[7] S.R. Septyawan, Learning Obstacles pada Konsep Fungsi: Sebuah Studi Fenomologi Hermeneutik (Skripsi), Bandung: Universitas Pendidikan Indonesia, 2018.

[8] S. Saifiyah, F. Ferdianto, and Setiyani, "Desain Modul Pembelajaran Berbasis Kemampuan Komunikasi Matematis dan Motivasi Belajar Siswa," KALAMATIKA Jurnal Pendidikan Matematika, vol. 2, no. 2, pp. 177-192, 2017.

[9] S.M. Rohimah, "Analisis Learning Obstacle pada Materi Persamaan dan Pertidaksamaan Linier Satu Variabel,” JPPM, vol. 10, no. 1, 2017.
[10] G. Brousseau, Theory of Didactical Situations in Mathematics, Dordrecht: Kluwer Academic Publishers, 2002.

[11] Y. Yusuf, N. Titat, and T. Yuliawati, "Analisis Hambatan Belajar (Learning Obstacle) Siswa SMP Pada Materi Statistika," Aksioma, vol. 8, no. 1, 2017.

[12] F. Ferdianto, Setiyani, and R.D. Widiyanti, "Development of teaching materials in the linear program of class XI," International Conference on Mathematics and Science Education (ICMScE 2018), pp. 032096, 201 